\title{
Polymer and Polar Material Content Determination as Basis for Assessing Thermally Oxidative Deterioration of Soybean Oil for Potato Heat Cooking
}

\author{
Kyoko HARA*, Kiyoshi HASEGAWA**, Yasushi ENDO** \\ and Kenshiro FuJimoto** \\ *Miyagi University of Education \\ (Aramaki, Aoba-ku, Sendai-shi, $\mathbf{T} 980$ ) \\ **Faculty of Agriculture, Tohoku University \\ (1-1, Tsutsumidori-Amamiyamachi, Aoba-ku, Sendai-shi, ₹ 981)
}

\begin{abstract}
Polymer and polar material content in soybean oils for deep-fat frying and pan frying sliced potatoes was determined so as to assess the thermally oxidative deterioration of soybean oil. Polymer and polar material content was found to increase with heating time of deep-fat frying and pan frying, and closely correlated to chemical characteristics such as iodine, acid, peroxide, and carbonyl values and color tone of soybean oils heated for potato cooking.
\end{abstract}

\section{Introduction}

As the cooking style of deep-fat frying and pan frying has become more popular and the intake of heated oils has been increased in Japan, the toxicity of heated oils which are often reused for deep-fat frying and pan frying has been made issue. Therefore, it is required to estimate the quality of heated and cooked oils. The chemical characteristics such as acid value and peroxide value were generally applied for assessing thermally oxidative deterioration of heated and cooked oils. In the previous paper ${ }^{1)}$, we have reported that the polymer and polar material contents in heated soybean oils showed a good correlationship with chemical characteristics.

In this study, polymer and polar material contents were measured for soybean oils used for deep-fat frying and pan frying sliced potatoes to reconfirm whether they could be available as indicators of the thermally oxidative deterioration of vegetable oils during actual heat-cooking instead of

Corresponding author : Kyoko HARA conventionally used chemical characteristics.

\section{Experimental}

Refined, bleached and deodorized soybean oil was provided from Ajinomoto Co. Potato was purchased at a local market and sliced at thickness of $1 \mathrm{~cm}$.

Soybean oil was heated in two system (deep-fat frying, and deep-fat frying and successive pan frying). As for deep-fat frying, $1 \mathrm{~kg}$ of soybean oil were placed in a steel pan and then maintained at $180^{\circ} \mathrm{C}$ as described previously ${ }^{1)}$. One hundred grams of round sliced potatoes were fried for 10 min every $20 \mathrm{~min}$. Frying potatoes was repeated for $6 \mathrm{~h}$ a day and was finally carried out for $30 \mathrm{~h}$. During heating for deep-fat frying, $55 \mathrm{~g}$ of heated soybean oils were periodically collected and then immediately cooled. Aliquots of sample oils (10 g) was heated again at $180^{\circ} \mathrm{C}$ for pan frying sliced potatoes $(200 \mathrm{~g})$ for 5 or $10 \mathrm{~min}$.

Ploymer and polar material contents in sample oils were determined by high performance liquid chromatography using a gel 
permiation column, GP-HPLC(TSK GEL G $2500 \mathrm{HXL}$, Toyo Soda) and thin layer chromatography with a flame ionization detector, TLC-FID(Iatroscan TH-10, Iatron Laboratories Inc.), respectively, as described in the previous paper ${ }^{1)}$.

Iodine (IV), acid (AV), and peroxide values (PV) were measured in according to the conventional methods ${ }^{2)}$. Carbonyl value(CV) was determined by the method established by Kumazawa and Oyama ${ }^{3)}$. Color tone was determined by measuring the optical density (OD) of benzene solution at $440 \mathrm{~nm}^{1}$ ).

\section{Results and Discussion}

Typical chromatograms of polymers in soybean oils used for deep-fat frying, and deep-fat frying and successive pan frying of potatoes obtained by GP-HPLC analysis are shown in Fig. -1 . Dimer and oligomers

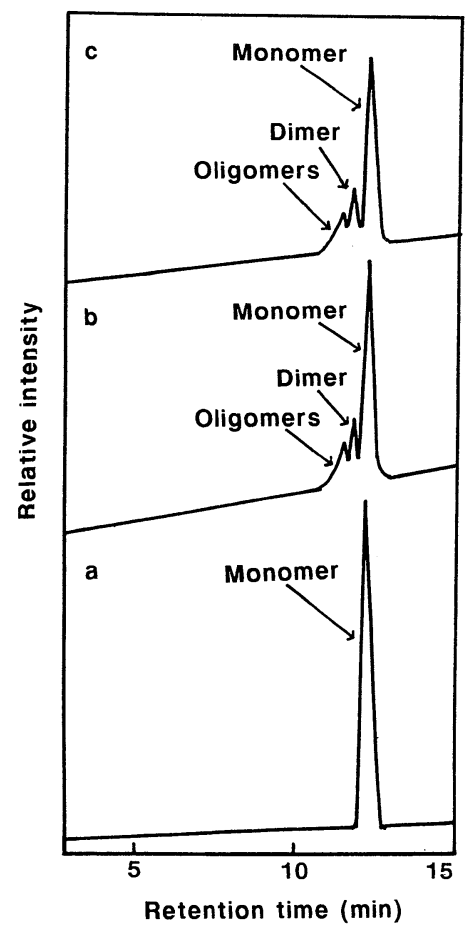

a : Fresh

b : Deep-fat frying for $30 \mathrm{~h}$

c : Deep-fat frying for $30 \mathrm{~h}$ and successive pan frying for $10 \mathrm{~min}$

Fig.-1 GP-HPLC analysis of polar materials in soybean oils used for heat cooking of potatoes. were found as polymers in soybean oil used for frying potatoes besides monomer, while only monomer was found in fresh soybean oil. These observations were very similar to those of heated soybean oils without cooking potatoes.

Dimer and oligomers compositions in soybean oils used for cooking potatoes are shown in Table-1. The ratio of dimer and oligomers in both oils after deep-fat frying, and deep-fat frying and successive pan frying increased linearly according to heating time, while the ratio of monomer gradually decreased. A major polymer was dimer in soybean oils heated until $20 \mathrm{~h}$, but oligomers content was more than dimer content at 30 h. The total ratios of polymers followed the order of deep-fat frying+pan frying for 10 min>deep-fat frying + pan frying for $5 \mathrm{~min}>$ deep-fat frying. These observations showed the total ratios of polymers in heated soybean oils depended on heating time, and were similar to those in the case that sunflower oil was used ${ }^{4)}$. On the other hand, the total ratios of polymers in soybean oils heated with frying potatoes for $30 \mathrm{~h}$ were $31 \sim 36 \%$, and they were notably lower than those in heated oils without frying (38 55\%).

Table-1 The composition (\%) of polymers in soybean oils used for heat cooking of potatoes.

\begin{tabular}{l|r|r|r}
\hline \multirow{2}{*}{} & \multicolumn{3}{|c}{ Heating time } \\
\cline { 2 - 4 } & $10 \mathrm{~h}$ & $20 \mathrm{~h}$ & $30 \mathrm{~h}$ \\
\hline Deep-fat frying & & & \\
Monomer & 89.6 & 75.4 & 68.8 \\
Dimer & 8.6 & 15.0 & 15.9 \\
Oligomers & 1.8 & 9.6 & 15.3 \\
\hline Deep-fat frying & & & \\
+pan frying(5 min) & & & \\
Monomer & 86.1 & 76.3 & 67.1 \\
Dimer & 9.2 & 13.2 & 15.3 \\
Oligomers & 4.7 & 10.5 & 17.6 \\
\hline Deep-fat frying & & & \\
+pan frying(10 min) & & & \\
Monomer & 84.7 & 74.7 & 64.1 \\
Dimer & 9.6 & 14.2 & 17.8 \\
Oligomers & 5.7 & 11.1 & 19.1 \\
\hline
\end{tabular}


Addition of potatoes might reduce the temperature temporarily and result in the retarded formation of polymers.

Typical chromatograms of polar materials in soybean oils used for frying potatoes obtained by TLC-FID analysis are shown in Fig.-2. A peak which located at origin was regarded as a major polar material in soybean oil used for heat cooking of potatoes, while only one peak corresponding to triacylglycerol was found in fresh soybean oil. These chromatograms were similar to those in heated soybean oils without cooking potatoes. When all peaks other than the triacylglycerol peak were quantatively analyzed by TLC-FID as polar materials peaks, polar materials content was lower in soybean oil

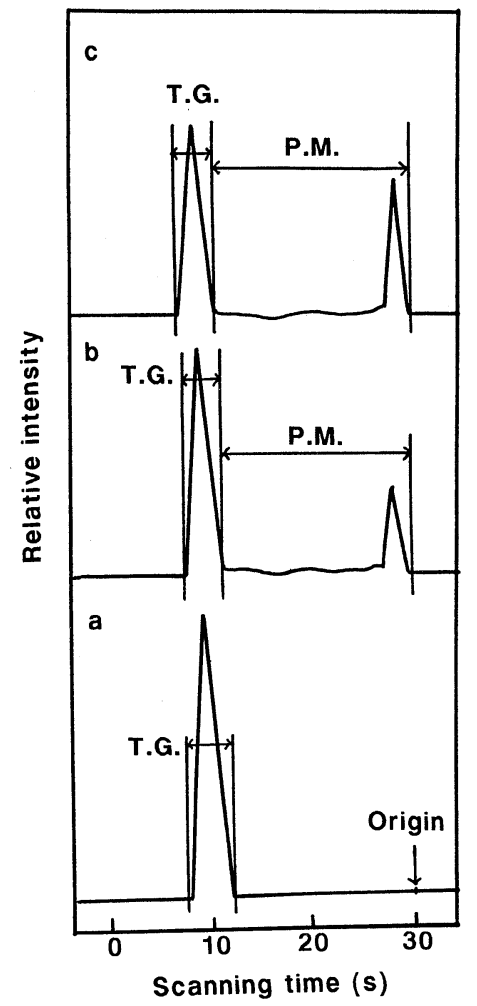

\footnotetext{
a : Fresh

b : Deep-fat frying for $30 \mathrm{~h}$

c : Deep-fat frying for $30 \mathrm{~h}$ and successive pan frying for $10 \mathrm{~min}$

P. M. : Polar materials, T. G. : Triacylglycerol
}

Fig.-2 TLC-FID analysis of polar materials in soybean oils used for heat cooking of potatoes. used for frying than in heated soybean oil without frying. It seemed to be due to that thermal oxidation was retarded by the reduction of heating temperature immediately after addition of potatoes.

The contents of polymers and polar materials in soybean oil produced during heating for deep-fat frying and pan frying sliced potato was shown in Fig. -3 . The total content of polymers which consisted of dimer and oligomers increased linearly with heating time. The content of polymers in soybean oil after deep-fat frying and successive pan frying was slightly higher than that in soybean oil after just deep-fat frying. The polar material contents also increased in progress of heating time, while intact triacylglycerols decreased. Especially, higher contents of polar materials were observed in soybean oil after deep-far frying and successive pan frying than in soybean oil after deep-fat frying. There was a good positive correlation $(r=0.978)$ between polymer and polar material contents until $20 \mathrm{~h}$-heating. It was very interesting that polar material contents in heated and cooked soybean oil
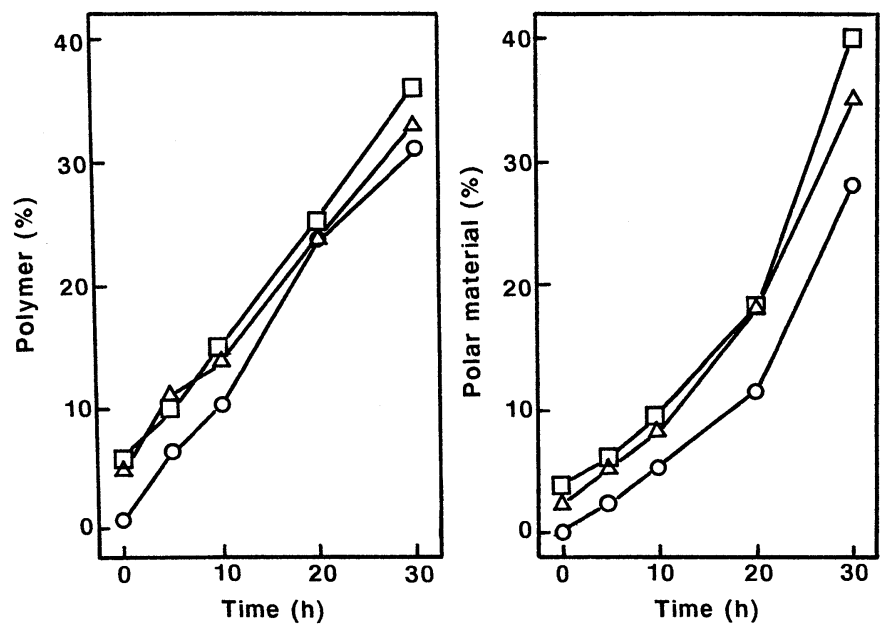

o : Deep-fat frying

$\triangle$ : Deep-fat frying and successive pan frying for $5 \mathrm{~min}$

$\square$ : Deep-fat frying and successive pan frying for $10 \mathrm{~min}$

Fig.-3 Polymer and polar material contents in soybean oils used for heat cooking of potatoes. 
Table-2 Correlation coefficients between polymer and polar material contents and chemical characteristics of soybean oils used for heat cooking of potatoes.

\begin{tabular}{|c|c|c|c|c|c|}
\hline & IV & $\mathrm{AV}$ & PV & $\mathrm{CV}$ & OD \\
\hline Deep-fat frying & & & & & \\
\hline Polymer & -0.983 & 0.978 & 0.984 & 0.991 & 0.954 \\
\hline Polar material & -0.956 & 0.982 & 0.955 & 0.975 & 0.986 \\
\hline $\begin{array}{l}\text { Deep-fat frying } \\
+ \text { pan frying }(5 \mathrm{~min})\end{array}$ & & & & & \\
\hline Polymer & -0.992 & 0.994 & 0.985 & 0.995 & 0.992 \\
\hline Polar material & -0.989 & 0.965 & 0.944 & 0.971 & 0.958 \\
\hline $\begin{array}{l}\text { Deep-fat frying } \\
+ \text { pan frying }(10 \mathrm{~min})\end{array}$ & & & & & \\
\hline Polymer & -0.999 & 0.932 & 0.997 & 0.989 & 0.964 \\
\hline Polar material & -0.963 & 0.977 & 0.937 & 0.988 & 0.993 \\
\hline
\end{tabular}

$\mathrm{IV}$, iodine value ; $\mathrm{AV}$, acid value ; $\mathrm{PV}$, peroxide value ; CV, carbonyl value ; OD, optical density at $440 \mathrm{~nm}(n=12)$

remarkably increased after deep-fat frying for more than $20 \mathrm{~h}$ as well as the formation of crab froth. The polymer content, however, increased after $20 \mathrm{~h}$-frying but less distinct. As polar materials were mostly the highly polar polymers after 20 h-heating, some of them were found to be absorbed on the polystyrene gel used for GP-HPLC. As the formation of highly polar materials was also recognized by thin layer chromatography, the determination of polar materials may be preferable over that of polymers by gel permiation chromatography. The formation of highly polar materials as absorbed on the gel column was not observed in the heated oil without frying previously reported ${ }^{1)}$.

The correlation coefficients between the contents of polymers and polar materials, and chemical characteristics in soybean oil heated for deep-fat frying and pan frying sliced potatoes are shown in Table-2. Both polymer and polar material contents showed a good correlation $(p<0.01)$ with all chemi- cal characteristics, although their changes were relatively small. These results were in consistence with the result of Sanchez-Muniz et al. ${ }^{4)}$ who used sunflower oil. The composition of dimer and oligomers, and polar materials produced during heat cooking was influenced by heating time and temperature but not the oil type. Our data demonstrated that both the polymer and polar material contents could be available as indicators of the thermally oxidative deterioration of vegetable oils heated for actual cooking.

(Received June 30, 1993)

\section{References}

1) K. Hara, S.-Y. Cho, and K. Fujimoto, $J$. Jpn. Oil Chem. Soc. (YUKAGAKU), 38, 463 (1989).

2) Japan Oil Chemists' Society Ed., "Standard Methods for the Analysis of Oils and Fats, and Derivatives", 1981.

3) H. Kumazawa and T. Oyama, Yukagaku, 14, 167 (1965).

4) F.J. Sánchez-Muniz, C. Cuesta, and C. Garrido-Polonio, J. Am. Oil Chem. Soc., 70, 235 (1993).

\section{重合物量及び極性物質量によるポテトの 加熱調理に用いた加熱大豆油の 劣化度の評価}

原 京子* - 長谷川 清** ・ 遠藤 泰志 ${ }^{* *}$ 藤本健四郎 ${ }^{* *}$

*宮城教育大学 ( 9980 仙台市青葉区荒巻)

**東北大学農学部 ( 9981 仙台市青葉区堤通雨宮町 1-1)

ポテトをフライ及びいた(炒)めた時の加熱大豆油の劣 化度を重合物量及び極性物質量から追跡した。大豆油中 の重合物量及び極性物質量は, 加熱時間に伴って増加 し, 加熱油の劣化度の測定に従来から用いられている化 学特数や色調と高い相関性を示した。以上より, 重合物 量及び極性物質量の測定は，加熱調理に使われた食用油 の劣化度を判定するのに有効と思われた。

連絡者: 原 京子 